\title{
Research
}

\section{Exploring Social Resilience in Madagascar's Marine Protected Areas}

\author{
$\underline{\text { Joshua Cinner }}^{1}, \underline{\text { Mariana M. P. B. Fuentes }}^{1}$, and $^{\text {Herilala Randriamahazo }}{ }^{2}$
}

\begin{abstract}
We examined and compared aspects of local-level resilience in 13 coastal communities within and adjacent to all of Madagascar's national marine protected areas. Our examination of social resilience focused on indicators of the flexibility of household livelihood portfolios and both formal and informal governance institutions, the capacity of communities to organize, their capacity to learn, and access to household assets and community infrastructure. In general, we found high levels of flexibility in formal institutions and livelihood portfolios and high levels of participation in decision-making and community groups. Together, these indicators suggest some latent capacity to adaptively manage resources, but this capacity may be offset by poor levels of trust between communities and resource managers, a poor understanding of the ways in which humans affect marine resources, inadequate feedback of ecological monitoring to communities, inflexibility in informal governance institutions, and a lack of assets to draw upon. We suggest that building desirable resilience in Madagascar's marine protected areas will require the following: investments in community-level infrastructure, projects to generate household income, and enhanced agricultural production to improve the well-being of communities; improvements in the capacity to learn through investments in formal and informal education; enhanced trust between park staff and local communities; empowerment of communities to govern and enforce natural resources; the increased accountability of leaders and transparency of governance processes; adequate cross-scale interaction with local, provincial, and national institutions; and the pursuit of these activities in ways that capitalize on community-specific strengths, such as high flexibility and the presence of sociocultural institutions such as taboos that regulate resource use.
\end{abstract}

Key Words: resilience; coral reefs; socioeconomic aspects; marine protected areas; Madagascar

\section{INTRODUCTION}

Because of high levels of endemism and species diversity, Madagascar is considered a biodiversity hotspot (Myers et al. 2000). Consequently, it is a key focal area for international conservation efforts. In 2003, Malagasy President Ravalomanana announced that by 2009 Madagascar would have created a 6 million-ha network of terrestrial and marine reserves to protect its unique biodiversity, effectively tripling the area under protection (Duffy 2006). Although Madagascar's commitment to conservation is an important contribution to global conservation, only a few studies have examined conservation in Madagascar from the point of view of resilience (Bodin et al. 2006, Janssen et al. 2006).

Resilience is the ability of a social-ecological system to cope with and adapt to external social, political, or environmental disturbances (Folke et al. 2002, Adger 2006, Gallopin 2006, Marshall and Marshall 2007). Resilience can be a positive attribute; for example, a desirable social-ecological system can absorb multiple perturbations before shifting to an undesirable state. It can also be a negative attribute, in that an undesirable configuration may persist despite attempts to change it to a desirable one. Scientists, governments, and natural resource managers have become increasingly interested in applying resilience to conservation initiatives by actively managing for the resilience of social-ecological systems (Hughes et al. 2005, Lebel et al. 2006, Marshall and Marshall 2007). Managing resilience means actively building or eroding aspects of a particular system configuration to either prevent the system from moving to an undesirable state or push the system to a more desirable state (Walker et al. 
2002, Lebel et al. 2006). In practice, managing resilience entails: (1) understanding the key components of resilience, how they are linked, and how they are affected by external drivers; (2) nurturing the positive elements of resilience and eroding the negative ones; (3) adaptively or experimentally managing resources as social, economic, or ecological conditions change; (4) where necessary, creating or improving linkages across spatial and temporal scales; and (5) embracing disturbances as opportunities for change and transformation to more desired states (Walker et al. 2002, Hughes et al. 2005).

The nation of Madagascar is vulnerable to chronic stresses and recurring disturbances. Part of that vulnerability or lack of resilience is because of extreme poverty. Most $(61 \%)$ of the inhabitants subsist on incomes of less than U.S. $\$ 1 /$ d, and $40 \%$ consume less than the minimum daily nutritional requirement (UN 2007). External disturbances that coincide with internal vulnerabilities generate a range of crises. Some are ecological crises, such as deforestation (Kull 2000, Marcus 2001, Barrett et al. 2006) or recurring tropical storms. For example, in the 2006-2007 season, six major cyclones hit the island, leaving over half a million people in need of humanitarian aid (Reuters 2007). Other crises are political or economic, such as the 10-fold fluctuation in the price of vanilla crops in 2005 (International Trade Centre Market News Service 2005). Likewise, a six-month presidential crisis in 2002 caused the suspension of flights to Madagascar (Duffy 2006). To date, there has been little research examining the capacity of social-ecological systems in Madagascar to cope with or adapt to disturbances.

In a comparison of national-level social vulnerability across Africa, Madagascar ranked as the most vulnerable country (Adger and Vincent 2005). This suggests that Madagascar is highly susceptible to the impacts of disturbances. Although this index deals specifically with human vulnerability to fluctuations in water availability caused by climate change, it incorporates indicators such as economic well-being and stability, institutional stability, the strength of public infrastructure, global interconnectivity, and dependence on natural resources. Many of these indicators are also relevant to vulnerability to other types of economic, ecological, and political events.

Given the turbulent social and ecological conditions that characterize Madagascar, it is important to understand how Madagascar's marine protected areas can be set up to manage resilience. One of the challenges for conservation practitioners attempting to understand and manage resilience in coral reefs is that many resilience frameworks (e.g., Walker et al. 2002) do not reflect the type of data commonly collected during socioeconomic monitoring of conservation projects (e.g., Pollnac 1998, Bunce et al. 2000, Pollnac and Crawford 2000). Our goal for this paper is to develop and implement a framework in which the type of socioeconomic data that are regularly collected as part of coral reef management can be used to explore some key aspects of social resilience (Fig. 1). We use socioeconomic monitoring data to examine aspects of social resilience at the scale of the social-ecological system in a marine protected area (MPA) that encompasses one to five communities. We examine and compare four local-level resilience characteristics in communities adjacent to Madagascar's national MPAs. These are flexibility (Gunderson 1999, Adger 2000), assets (Adger 2000), the capacity to learn (Carpenter et al. 2001, Lebel et al. 2006), and the capacity to organize (Carpenter et al. 2001, Lebel et al. 2006). To highlight which specific aspects of resilience could potentially be bolstered or developed in attempting to manage the resilience of Madagascar's expanding MPA network, we compare indicators of these four key resilience characteristics. Where possible, we also describe how these indicators are linked to regional and national scales (e.g., Berkes and Seixas 2006).

\section{Study sites and institutions governing marine resources}

We conducted research in 13 communities in northern Madagascar between September and November 2005 in communities located within or adjacent to national MPA boundaries (Fig. 2). Communities were selected specifically to encompass a range of socioeconomic conditions such as population size, development, and dependence on marine resources. All of Madagascar's MPAs are located in remote areas away from large urban centers. It should be noted that, technically and administratively, the Tampolo, Tanjona, and Cap Masoala MPAs are all part of the Masoala national park. We surveyed all of the communities in the Tampolo and Tanjona MPAs, but only $50 \%$ of the communities in Sahamalaza and one of four communities adjacent to the Nosy 
Fig. 1. Conceptual framework for exploring social resilience. The four key clusters of social resilience are flexibility, capacity to learn, capacity to organize, and assets. In a resilient system, one would expect each cluster to be robust and linked at the local, regional, and national levels. A nonresilient system may have a weak cluster or lack linkages across scales.

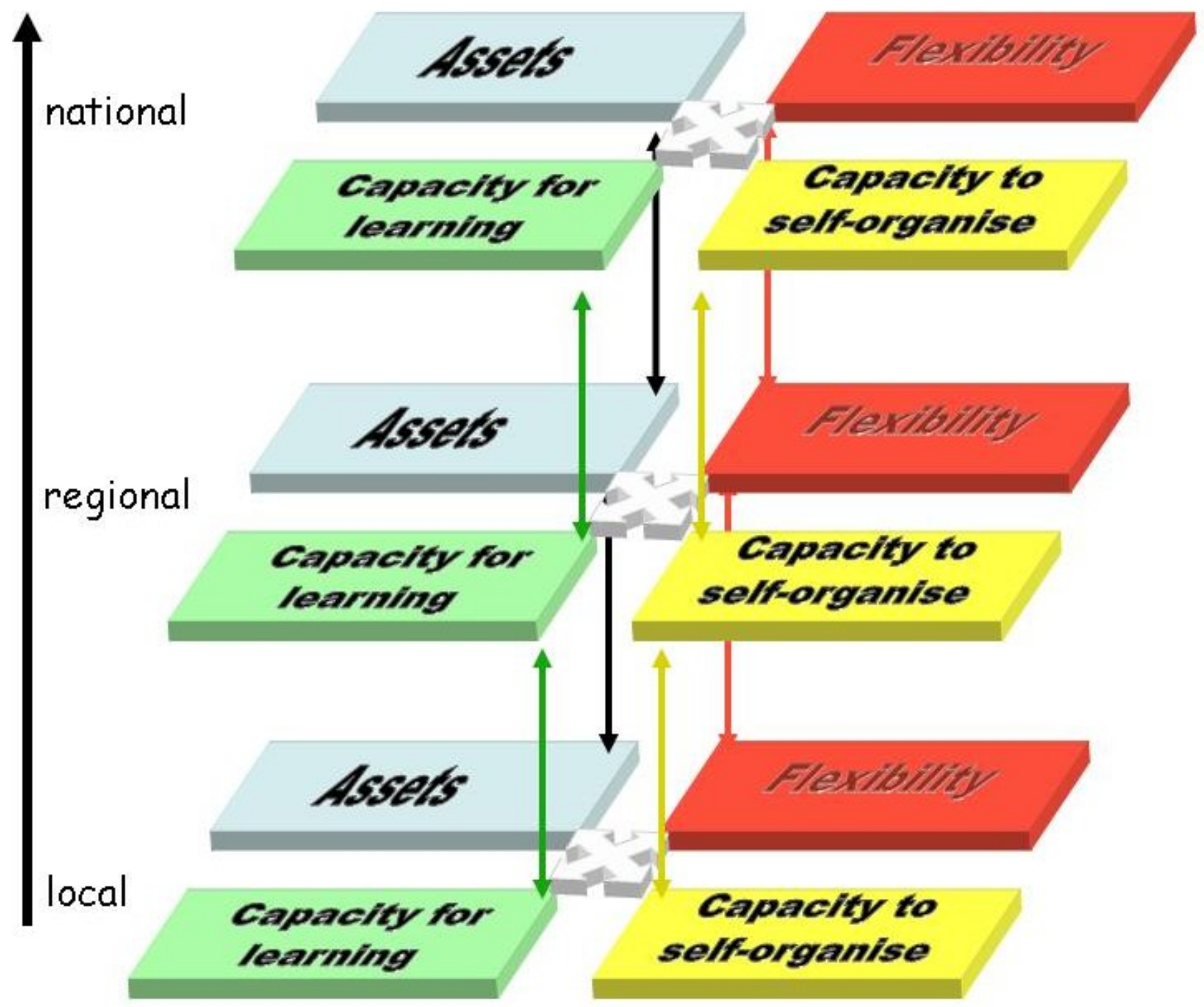

Atafana MPA. The community we studied in the Nosy Atafana MPA is the largest of the four communities and contains about $50 \%$ of the population adjacent to that park. Our study sites cover all the officially designated MPAs in Madagascar. The study villages were not randomly selected, so care should be taken when generalizing the study results.
No-take zones in which fishing is prohibited exist in all of the MPAs. In Tanjona, Tampolo, and Cap Masoala, only local residents can use the multipleuse zone of the marine reserves. In each of these three areas, the no-take portion of the reserve is approximately $10 \%$ of the total area. This results in a total of approximately $10 \mathrm{~km}^{2}$ of no-take area. 
Fig. 2. Map of study sites within and adjacent to Madagascar's marine protected areas.
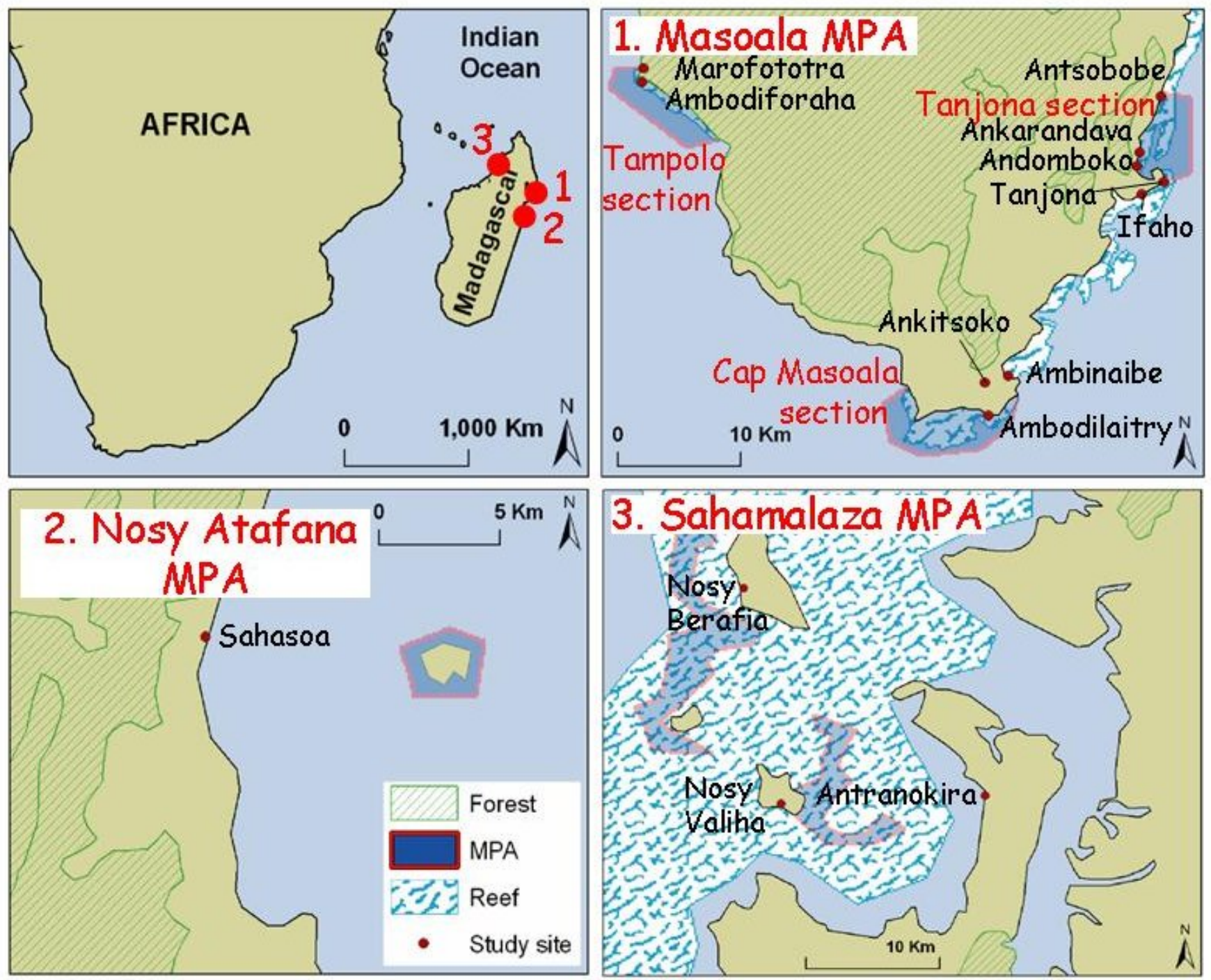

The Nosy Atafana marine park is a circular area with a diameter of $4 \mathrm{~km}$ that covers approximately 1000 ha, including a 20-ha no-take area (ANGAP 2002, Gell and Roberts 2003). In the communities around the Nosy Atafana MPA, it is taboo to farm on Tuesdays and Thursdays (Cinner 2007). Consequently, those are the de facto fishing days for most residents. In an effort to make the park more reflective of the local socioeconomic circumstances, the Association nationale pour la gestion des aires protégées (ANGAP), i.e., the national association for the management of protected areas, renegotiated the rules of the park to allow fishing in the multiple-use parts of the park on Tuesdays, Thursdays, and Sundays (Cinner 2007). In addition, the Madagascar government has begun transferring management authority (transfert de gestion) for both marine and terrestrial resources to communities and NGOs (Kull 2002, Cinner et al. 2009c). Compliance records at Nosy Atafana suggest low levels of recorded offences: Between 1998 and 2000, there were three to five incidents per year of fishing in 
no-take areas and eight to 14 incidents per year of using prohibited gear (Gell and Roberts 2003). In addition to government-based management such as MPAs, two forms of informal institutions also govern marine resource use in Madagascar: the traditional social code known as dina and local taboos known as fady. Dina is a social code developed and enforced at the local level (Kull 2002, Rakotoson and Tanner 2006). In parts of Madagascar, dina is used to establish and enforce local fishing regulations (Rakotoson and Tanner 2006). However, at our study sites dina is not used for this purpose.

A number of studies (e.g., Ruud 1960) describe Malagasy taboos (fady) and their social role (Lambek 1992, 1998, Walsh 2002). However, few studies examine taboos that restrict resource use and their potential roles in conservation (Lingard 2003, Bodin et al. 2006, Louden et al. 2006), particularly in the marine environment (Cinner 2007). Local taboos at our study sites include restrictions on certain marine species such as guitarfish (Rhinobatos productus), red snapper (Lutjanus campechanus), and sea turtles (Cheloniidae spp.; Cinner 2007). Taboos also restrict the days on which people can work in the rice fields. These taboos can serve to limit the number of fishing days for those who consider fishing secondary to agriculture. There are sacred marine areas at Cap Masoala, Sahamalaza, and Nosy Atafana in which fishing is restricted or prohibited (Cinner 2007). Virtually all of the local resource-use taboos are highly specific in nature; for example, dietary restrictions are often limited to a particular family or clan.

At Tanjona, Tampolo, and Cap Masoala, ecological monitoring of the condition of coral reefs and fisheries resources has been ongoing for several years. At these sites, monitoring has occurred at least sporadically since 1999 (Randriamanantsoa and Lope 1999) and is conducted by consultants, ANGAP rangers, and international NGO staff. At Nosy Atafana, ecological monitoring is more sporadic but has also been taking place since at least 1999 (Wilkinson 2000). At Sahamalaza, ecological monitoring was just beginning when this research got under way.

\section{METHODS}

We gathered information using several techniques, including household surveys and interviews with key informants and community leaders. A household was defined as people living together and sharing meals. In communities of fewer than 30 households, we attempted to survey every household, but this was never achieved because of the long-term absences of certain residents. In larger communities of greater than 30 households, we selected the households to be surveyed based on a sample design in which we would survey every second or third household in a village (Henry 1990).

In total, 264 households were surveyed in the 13 communities adjacent to the five parks. The number of surveys per community ranged from seven to 44 . The number of surveys per park ranged from 43 to 70. The head of the household was individually interviewed in the national language (Malagasy) with a structured survey form administered by a trained research assistant. The household interview contained both open-ended and fixed questions that are described below.

Our key informants included park rangers, managers, and scientists from ANGAP; NGO staff; and knowledgeable community members such as community elders, a queen, and elected officials. Key informants were individually interviewed. We selected key informants using nonprobability sampling techniques. We organized our data around four key clusters of resilience: flexibility, capacity to organize, capacity to learn, and assets (Table 1).

\section{Flexibility indicators}

As indicators of flexibility, we used quantitative data about dependence on natural resources and livelihood diversity, as well as descriptions of the formal and informal institutions that govern marine resources (Adger 2000, Cumming et al. 2005). We examined dependence on fishing and other livelihood activities by asking respondents to list all of the jobs the people in the household engaged in for food or money. We grouped occupations into the following categories: fishing, selling marine products, tourism, farming, cash crops, gleaning, salaried employment, and the informal sector. For our purposes, gleaning is the collection of marine organisms from shallow or intertidal areas, and it 
Table 1. Summary, brief description, and methods used to examine indicators of flexibility, capacity to organize, capacity to learn, and assets. $\mathrm{KI}=$ key informant interview, $\mathrm{HS}=$ household survey, $\mathrm{SI}=$ secondary information, and $\mathrm{PO}=$ participant observation.

\begin{tabular}{l}
\hline Measure \\
\hline Flexibility \\
Dependence on natural resources \\
Livelihood diversity \\
Linkages and feedbacks between \\
marine and terrestrial resource use \\
sectors
\end{tabular}

Descriptions of formal and informal institutions used to govern resources

\section{Capacity to organize}

Involvement in community organizations

Participation in community decision making

Migration

Capacity to learn

Perceptions about humans as causal agents in marine ecosystems

Education

Monitoring of resources

Assets

Material style of life

Infrastructure
Description of indicators

Methods

Importance of fishing and other natural-resource-based KI, HS occupations to household income and food security

Number of different occupations per household

$\mathrm{KI}, \mathrm{HS}$

Open-ended questions about how the 2005 fluctuation KI, HS in the price of vanilla affected the respondent's livelihood (Tanjona park only)

Open-ended questions about the rules, regulations, and KI, SI degree of compliance with taboos ( $f a d y)$, marine parks, and other institutions that govern resources

The number of community groups respondents were involved in

Ordinal score representing how involved respondents were in community decision-making processes

Whether respondents were born in the community or local region, i.e., within $75 \mathrm{~km}$

Responses to open-ended questions such as "How can HS you affect the number of fish in the sea?" and "What can be done to increase the number of fish in the sea?"

Years of formal education

HS

Qualitative descriptions about the presence of and KI, SI feedback from ecological monitoring

Material style of life indicators, including type of KI, HS, PO walls, roof, and floor and number and type of appliances in a household

Presence of key community-level infrastructure such as a medical center, hard-top roads, a school, etc. 
generally focuses on octopus and sea cucumbers. The informal sector activities included ownership of a small shop, sales of food or clothes from a kiosk, casual work, etc.

We then asked respondents to rank these activities in order of importance. Livelihood diversity was examined by counting the number of different occupational categories engaged in by a household. Key informants provided information about formal and informal institutions governing marine resources and about the impacts of the change in the price of vanilla on marine resource use. In the five communities adjacent to the Tanjona MPA, we asked respondents an open-ended question about how the drop in the vanilla price in 2003 affected their use of marine resources. These responses were grouped into the following categories: increase in fishing effort, no change in fishing effort, decrease in fishing effort, and don't know.

\section{Indicators of the capacity to organize}

Our indicators of the capacity to organize included quantitative data on involvement in community organizations, migration, community decision making, and population (Putnam 1993, Adger 2000, Carpenter et al. 2001, Pretty and Ward 2001, Lebel et al. 2006). We determined the total population for each area by multiplying the mean number of occupants per house by the total number of houses in the area. We also used secondary sources where available. Respondents were asked whether they belonged to any community organizations and whether they were involved in community decision making. All those who said that they did were asked to describe the type and number of these organizations and how they were involved in community decision making. Respondents were considered active in decision making if they had leadership positions and/or actively spoke during community meetings. Respondents were considered passive if they attended meetings but did not talk. Respondents were also asked where they were from. If they came from another village, they were considered immigrants. They were considered nonregional immigrants if they came from more that $75 \mathrm{~km}$ outside the study site.

\section{Indicators of the capacity to learn}

As indicators of the capacity to learn, we used quantitative data on how communities perceive the ability of human activities to negatively or positively affect marine resources, the number of years of formal education, and qualitative descriptions of resource monitoring (Carpenter et al. 2001, Tompkins 2005, Lebel et al. 2006). We asked respondents how many years of formal education they had completed. To understand perceptions about human agency in the environment, respondents were asked, "What can affect the number of fish in the sea?" They were also asked about the mechanisms by which their response could affect the number of fish in their local environment. For example, if a respondent mentioned that gill nets could affect the number of fish in the sea, he or she was asked to explain how. Responses were then grouped into relevant categories, and one response could fit into more than one category. Respondents were also asked "What could be done around [this community] so that there would be more fish in the sea?"

\section{Assets indicators}

Our indicators of assets included quantitative data on material life-style and community-level infrastructure (Adger 2000, Pollnac and Crawford 2000). Relative wealth or social status within a community was identified by examining the Material Style of Life (MSL) of households (Pollnac and Crawford 2000, Cinner and Pollnac 2004). MSL is a method of measuring wealth based on the presence or absence of household possessions or structure. To determine culturally appropriate indicators of wealth, we asked key informants to describe the house of a rich person and the house of a poor person. We developed a list of 22 items such as a television, clock, radio, gas stove, and electrical generator as well as the type of walls, roof, and floor. We recorded the presence of these items during the household surveys. Key informants and observation provided information about the presence of key components of community infrastructure such as hospitals, medical clinics, doctors, dentists, primary and secondary schools, piped water, sewer pipes/ canals, sewage treatment facilities, electric service, telephone service, food markets, pharmacies, hotels or guest houses, restaurants, gas stations, public transportation, hard-top road access, and banking facilities (Pollnac 1998). 


\section{RESULTS}

\section{Flexibility findings}

Most study sites were similar in the mean number of occupations per household, with 3.0 in Tampolo, 3.1 in Cap Masoala, and 3.2 in Tanjona and Nosy Atafana. However, Sahamalaza, the most rural and remote site, had considerably fewer occupations per household (2.2). The agricultural and cash crop sectors had the broadest participation and involved more than $92 \%$ of respondents (Fig. 3). The proportion of residents dependent on marine resources varied between parks. However, many of those who participated in the fishery considered it their most important occupation, particularly at Cap Masoala, Sahamalaza, and Tanjona (Fig. 3). Gleaning at all sites was less important than fishing, but did comprise a significant livelihood activity except in Tampolo. Occupations in the salaried employment sector accounted for $3 \%$, and those in the "other" sector, including remittances, traditional healing arts, etc. made up $9 \%$. Tourism is an important economic activity in parts of coastal Madagascar, but only $1 \%$ of respondents were involved in the sector, mostly as porters or local guides. Many key informants described changes in marine resource use after a major drop in vanilla prices from U.S. $\$ 400 / \mathrm{kg}$ to U.S. $\$ 35 / \mathrm{kg}$ in 2003 (International Trade Centre Market News Service 2005). One key informant noted that, "After the drop in vanilla prices, many people are now fishing." In the Tanjona MPA, $41 \%$ of fishers claimed that the drop in vanilla prices resulted in them fishing more. Alternatively, 29\% claimed that it had no impact on their use of marine resources, and $7 \%$ said that they fished less because the loss of income suffered by vanilla producers reduced the demand for and price of fish. Additionally $14 \%$ mentioned that they worked harder at other jobs, and 10\% didn't know or didn't respond.

\section{Capacity to organize findings}

Human population in communities adjacent to the parks ranged from 300 to more than 2275 people (Table 2). An average of $47 \%$ of all respondents immigrated to the study sites, but only $8.5 \%$ were not from the local area (Table 2). There was considerable variance around this mean, because the Tampolo and Tanjona parks had almost five-fold more immigrants than the Nosy Atafana MPA.
Almost every household interviewed reported involvement in decision making, and $40 \%-60 \%$ of households were actively involved (Table 2). However, decisions about natural resources at the village council level were reported to have weak links to decisions at the regional or national level. The mean number of community groups to which all households belonged was 0.6 (SD 0.7), and sites ranged from 0.3 to 0.9 (Table 2). Groups included conservation and development groups such as fishing and farming groups established by ANGAP to aid resource users. In Antongil Bay, an umbrella organization was established to represent the interests of all stakeholders in the coastal zone around the bay, including fishers at Tampolo and Cap Masoala. One consistent theme that arose in both informal interviews and in key informant interviews was a considerable criticism of ANGAP and the process through which they have instituted conservation in the protected areas. Multiple respondents in Sahasoa remarked that they had been asked to sign documents that stated that they were fishers to maintain their rights to fish in the Nosy Atafana MPA. ANGAP officials returned a week later and claimed that these people had signed a document agreeing not to harvest octopus and other species from the marine park. ANGAP officials at the Mananara office confirmed the respondents' story. As a result, general perceptions about ANGAP were quite negative, and there appeared to be little trust or good will between the community and ANGAP. Some respondents in the Cap Masoala MPA also felt excluded from the conservation process. One respondent noted that, "The marine park gives us a difficult life. There was no consultation with us when they instituted the park." Another respondent at Cap Masoala noted that the marine park's boundary markers are in violation of the taboos associated with the sacred area adjacent to the no-take area, and the park thus created negative spiritual forces.

\section{Capacity to learn findings}

The mean number of years of formal education of all respondents was only 3.2 (SD 3.0), and ranged from 2.5 at Sahamalaza to 5.2 at Nosy Atafana. Nosy Atafana was the only site with a mean of $>3 \mathrm{yr}$ of formal education. Many respondents noted that they received little if any feedback from the ecological monitoring programs regularly conducted in the parks. Less than $60 \%$ of respondents mentioned that 
Fig. 3. Percentage of households participating in select occupational sectors. The areas in black indicate the percentage of households that rank them as the primary occupation.

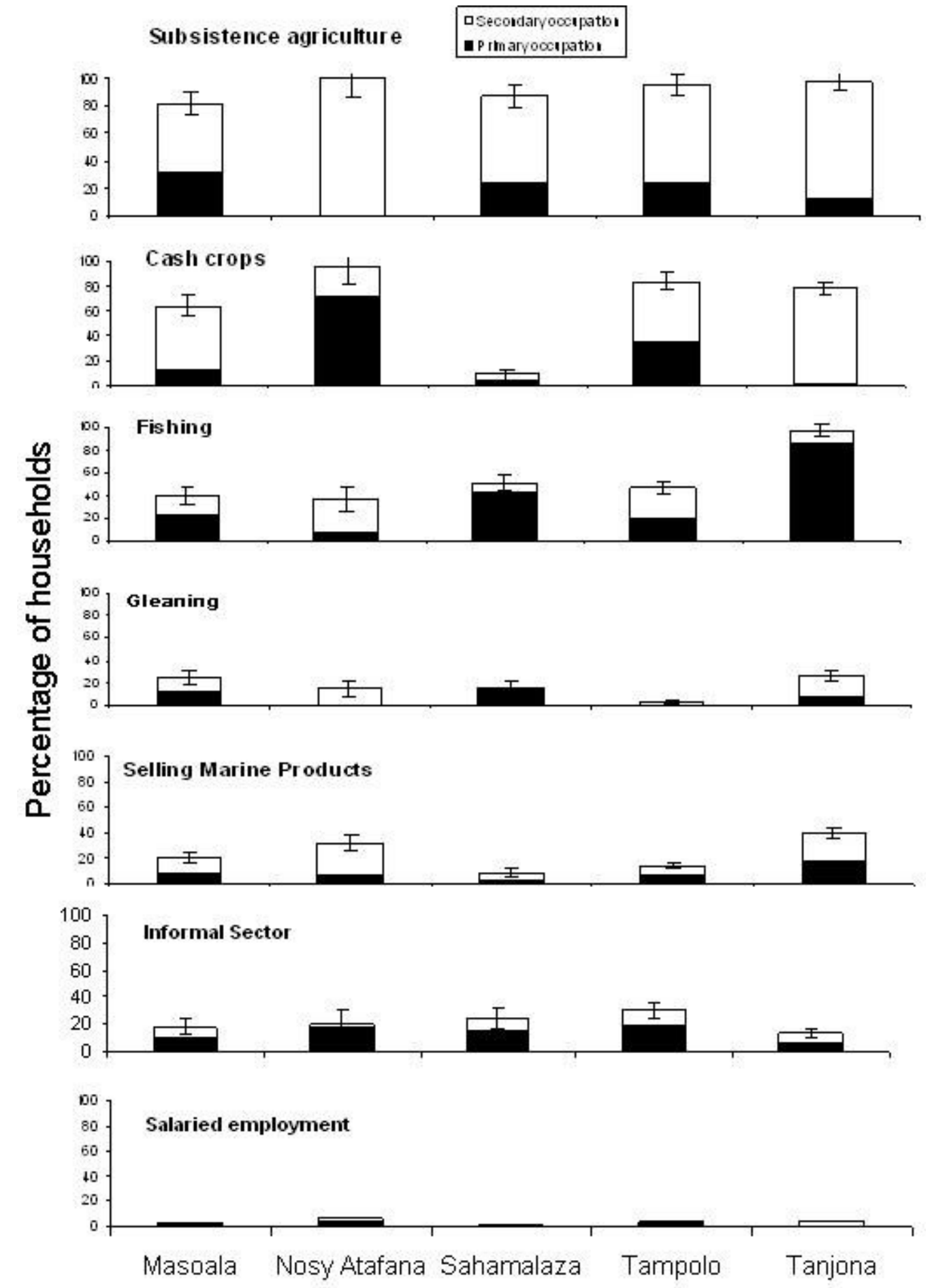


Table 2. Indicators of the capacity to organize at each study site, including involvement in community groups and decision making, population, and immigration at each study site. Community organizations = the mean number of community organizations local households were involved with, Decision making = the percentage of the community involved in decision making, Active in decision making $=$ the percentage of the community actively involved in decision making, Immigrants $=$ the percentage of respondents who were immigrants from the local area, and Nonregional = the percentage of respondents who were immigrants from outside the local area.

\begin{tabular}{lcccccc}
\hline \hline Site & $\begin{array}{c}\text { Community } \\
\text { organizations }\end{array}$ & $\begin{array}{c}\text { Decision } \\
\text { making }\end{array}$ & $\begin{array}{c}\text { Active in } \\
\text { decision } \\
\text { making }\end{array}$ & Population & Immigrants & Nonregional \\
\hline Nosy Atafana & 0.9 & 97.7 & 59.1 & $2275^{\dagger}$ & 15.9 & 6.8 \\
Cap Masoala & 0.3 & 94.9 & 43.4 & $1361^{\ddagger}$ & 60.5 & 13.1 \\
Sahamalaza & 0.8 & 100 & 54.3 & $585^{\S}$ & 32.9 & 5.7 \\
Tampolo & 0.5 & 97.7 & 55.8 & 286 & 72.1 & 2.3 \\
Tanjona & 0.6 & 92.3 & 42.3 & 316 & 53.8 & 15.4 \\
Average for all & 0.6 & 96.5 & 50.9 & 964 & 46.7 & 8.5 \\
sites & & & & & & \\
\hline
\end{tabular}

${ }^{\dagger}$ ANGAP 2002.

¥randcourt et al. 1999.

§Indicates only estimates for the study sites. There were additional hamlets in the park that we were not able to survey, so this is an underestimate of the true population dependent on the parks.

human activities could affect the number of fish in the sea, almost all of them referring to direct fishing activities. The most commonly mentioned factor affecting fish abundance (40\% of responses) was the number of fishermen, but the second most frequently cited response was "don't know" (Table 3 ). When asked about how the factors they mentioned could affect fish abundance, $25 \%$ of respondents described specific causal mechanisms. The most frequently cited mechanism was habitat destruction ( $10 \%$ of all responses). Only $2 \%$ of respondents mentioned that stochastic events such as cyclones, political/economic events, or climate change could affect the condition of the fishery, and $3 \%$ said that supernatural or religious factors can influence the fishery. Overall, $25 \%$ of respondents did not know what could improve the condition of the marine environment (Table 4). The most frequently cited responses were excluding outsiders, closing areas, limiting effort, reducing gill net use, and improving enforcement. Less than $20 \%$ of all respondents suggested that closed areas were a means to improve fishery resources. Tampolo had the highest proportion of interviewees mentioning closed areas (41\%). At other sites, only $10 \%-16 \%$ of interviewees mentioned closed areas.

\section{Assets findings}

Despite being in cyclone-prone areas, few houses were constructed from solid materials such as concrete walls or floors and metal roofs (Table 5). 
Table 3. Percentage of respondents at each site who mentioned specific factors that could affect the number of fish in the sea. Causal mechanisms explain how respondents believed the factor that they mentioned affects fish abundance. Respondents could mention more than one category, so the columns will not necessarily add up to $100 \%$.

\begin{tabular}{|c|c|c|c|c|c|c|}
\hline Response category & Cap Masoala & Sahamalaza & Tanjona & Nosy Atafana & Tampolo & All sites \\
\hline Human agency & 47 & 72 & 63 & 44 & 52 & 57 \\
\hline Fisheries & 45 & 72 & 63 & 44 & 52 & 57 \\
\hline Number of fishers & 31 & 62 & 48 & 23 & 31 & 41 \\
\hline Fishers from outside & 4 & 12 & 6 & 0 & 12 & 7 \\
\hline Nets & 14 & 6 & 23 & 23 & 7 & 14 \\
\hline Other gear & 8 & 3 & 2 & 2 & 5 & 4 \\
\hline Social/cultural factors & 4 & 2 & 4 & 0 & 0 & 2 \\
\hline $\begin{array}{l}\text { Stochastic events, e.g., climate } \\
\text { change, political conditions }\end{array}$ & 6 & 2 & 4 & 0 & 0 & 2 \\
\hline $\begin{array}{l}\text { Supernatural causes, e.g., gods, } \\
\text { ancestors }\end{array}$ & 0 & 2 & 0 & 14 & 2 & 3 \\
\hline Causal mechanisms & 24 & 12 & 25 & 40 & 29 & 25 \\
\hline Habitat & 18 & 6 & 15 & 9 & 2 & 10 \\
\hline Reproduction & 16 & 2 & 4 & 7 & 7 & 7 \\
\hline Life-history stages & 2 & 2 & 2 & 16 & 19 & 7 \\
\hline Fish mortality & 0 & 2 & 4 & 7 & 7 & 4 \\
\hline $\begin{array}{l}\text { Fish behavior, } \\
\text { e.g., moved, hiding }\end{array}$ & 4 & 3 & 6 & 14 & 2 & 6 \\
\hline Don't know & 33 & 14 & 23 & 16 & 33 & 23 \\
\hline
\end{tabular}

None of the households had access to electricity, and few possessed amenities such as radios, clocks, or mirrors. The community adjacent to the Nosy Atafana MPA had the highest proportion of respondents who owned items such as a radio, a metal roof, and wood plank floors, suggesting that this village had the highest MSL. All the communities were remote, and few had access to government services or facilities such as health care, schools, or transportation (Table 6). Sahasoa, the largest village surveyed, had the most amenities available. These consisted of a primary school, a medical clinic, a restaurant, sporadic public transportation via a dirt road, and small bungalows for rent. None of the other villages had roads, and there were few public services available. 
Table 4. Percentage of respondents in each community who mentioned specific factors that could improve the condition of the fishery. Respondents could mention more than one category, so the columns will not necessarily add up to $100 \%$.

\begin{tabular}{lcccccc}
\hline \hline Response category & Nosy Atafana & Cap Masoala & Sahamalaza & Tampolo & Tanjona & All sites \\
\hline Don't know & 18 & 41 & 17 & 26 & 27 & 26 \\
Exclude outside fishers & 0 & 19 & 16 & 30 & 27 & 18 \\
Closed areas & 14 & 10 & 16 & 42 & 11 & 18 \\
Reduce fishing effort & 18 & 7 & 23 & 7 & 7 & 13 \\
Reduce use of gill nets & 23 & 12 & 6 & 2 & 20 & 12 \\
Enforcement & 5 & 12 & 7 & 21 & 9 & 10 \\
Reduce use of seine nets & 9 & 5 & 3 & 2 & 9 & 5 \\
Social cohesion & 0 & 0 & 9 & 2 & 2 & 3 \\
Supernatural causes & 11 & 0 & 3 & 0 & 2 & 3 \\
Political/economic solutions & 0 & 0 & 3 & 2 & 2 & 2 \\
\hline
\end{tabular}

\section{DISCUSSION}

On a national level, Madagascar has been exposed to a broad range of chronic and stochastic socioeconomic, political, and ecological disturbances. These have contributed to a system state with consistently high poverty, child mortality, food insecurity, and malnutrition and a severely degraded natural resource base (Kull 2000, Marcus 2001, Barrett et al. 2006, UN 2007). Although nationallevel statistics can fail to reflect considerable heterogeneity in well-being, our coastal study sites were characterized by low levels of education, considerable poverty, and a lack of access to infrastructure such as schools or health care. Many conservation projects and national parks are located in the areas in which biodiversity is highest and natural resources are the least degraded, so that the ecosystem still maintains desirable resilience characteristics (McClanahan 2007). Conservation projects and even attempts to integrate conservation with development agendas in Madagascar have frequently failed to produce tangible results (Sussman et al. 1994, Peters 1998, Marcus and Kull 1999, Marcus 2001, Harper 2002, Kull 2002, West and Brockington 2006). This suggests that the social-ecological system in Madagascar may be in a resilient but highly undesirable configuration. As ecosystems become more degraded, shifting to a desirable state becomes more difficult. Adaptive capacity is the potential to cope with disturbances and take advantage of the new opportunities that result from climate impacts, conservation interventions, or other changes to the socialecological system (IPCC 2007).

In a direct comparison with coastal communities in Kenya, Tanzania, Mauritius, and the Seychelles, the adaptive capacity of our study sites in Madagascar was the lowest of all (McClanahan et al. 2008). This suggests that one reason why this undesirable state persists may be because communities are not able to take advantage of the opportunities arising from conservation, development, and other forms of change. Managing for resilience in Madagascar's MPAs will require an understanding of the existing components of resilience and the ability to both capitalize on those aspects of resilience that are desirable and change those that are not. This paper provides an original contribution by developing a 
Table 5. Distribution of household items, expressed as percentage of households with selected material possessions, and fortnightly expenditures in U.S. dollars.

\begin{tabular}{lccccc}
\hline \hline Item & Cap Masoala & Nosy Atafana & Sahamalaza & Tampolo & Tanjona \\
\hline Radio & 43.1 & 68.2 & 32.9 & 53.5 & 42.2 \\
Clock & 1.7 & 9.1 & 7.1 & 4.7 & 2.2 \\
Mirror & 17.2 & 6.8 & 8.6 & 4.7 & 17.8 \\
Thatch roof & 94.8 & 56.8 & 94.3 & 90.7 & 97.8 \\
Metal roof & 6.9 & 43.2 & 7.1 & 9.3 & 2.2 \\
Cement floor & 0.0 & 6.8 & 5.7 & 0.0 & 0.0 \\
Dirt floor & 0.0 & 0.0 & 1.4 & 0.0 & 4.4 \\
Wood floor & 29.3 & 56.8 & 0.0 & 14.0 & 4.4 \\
Bamboo floor & 74.1 & 38.6 & 94.3 & 83.7 & 91.1 \\
Wood wall & 5.2 & 54.5 & 0.0 & 4.7 & 2.2 \\
Bamboo wall & 96.6 & 43.2 & 98.6 & 95.3 & 97.8 \\
Outhouse toilet & 27.6 & 97.7 & 12.9 & 53.5 & 40.0 \\
Public toilet & 25.9 & 0.0 & 1.4 & 7.0 & 13.3 \\
No toilet & 53.4 & 2.3 & 87.1 & 37.2 & 44.4 \\
Average fortnightly expenditures/ & 14.9 & 7.4 & 13.9 & 11.2 & 14.9 \\
household & & & & \\
\hline
\end{tabular}

framework to explore some key aspects of social resilience that can be used with the type of socioeconomic data that are regularly collected in socioeconomic monitoring of coral-reef management systems. We explored how local socioeconomic conditions may be contributing to the conditions of undesirable resilience and low adaptive capacity and make recommendations for improving them.

\section{Flexibility}

One key aspect of resilience in social-ecological systems is the flexibility of resource users to switch from one livelihood strategy to another (Berkes and Sexias 2006). Madagascar's MPAs are located in remote rural areas whose human communities rely on marine and terrestrial resources for income and subsistence livelihoods. Most households have a variety of livelihood activities to draw upon. The average number of occupations per household is relatively consistent across sites and almost double the 1.7 mean occupations per household found in Kenya (Cinner et al. 2009a). However, the viability of some key occupations such as cash crops is sporadic and highly susceptible to disturbances such as price fluctuations or cyclones. Changes in the price of vanilla can heavily influence marine resource use in some areas, suggesting apparent substitutability links between the marine resource and cash crop sectors. On average, households in Sahamalaza engage in almost one fewer occupation than do households in the other parks, suggesting 
Table 6. Index of services and facilities (adapted from Pollnac 1998). X indicates that the service or facility was present. None of the communities had a hospital, a doctor, a dentist, a school, piped water, sewer pipes/ canals, sewage treatment facilities, an electric service, a telephone service, a food market, a pharmacy, a petrol station, hard-top road access, or banking facilities.

\begin{tabular}{|c|c|c|c|c|c|}
\hline Services/facilities & Cap Masoala & Nosy Atafana & Sahamalaza & Tampolo & Tanjona \\
\hline Medical clinic & & $\mathrm{X}$ & & & \\
\hline Primary school & $\mathrm{X}$ & $\mathrm{X}$ & $\mathrm{X}$ & $X$ & $X$ \\
\hline Hotel or guest house & & $\mathrm{X}$ & & $X$ & \\
\hline Restaurant & & $\mathrm{X}$ & & & \\
\hline Public transportation & & $X$ & & & \\
\hline
\end{tabular}

that livelihood strategies in Sahamalaza are less flexible. Enhancing flexibility through supplemental income strategies may be a key component of building resilience in this area.

Institutional flexibility provides the conditions necessary for experimentation and the ability to respond to change (Tomkins and Adger 2004, Berkes and Sexias 2006). A range of local resourceuse restrictions exists in the form of resource-habitat taboos (Ruud 1960, Colding and Folke 2000, Cinner 2007). Studies in Papua New Guinea and Indonesia show that customary management practices can be highly adaptive and conserve coral reef resources (Cinner et al. 2006). However, customary taboos related to resource use in Kenya (McClanahan et al. 1997) and Madagascar (Elmqvist 2004, Bodin et al. 2006) appear to be relatively inflexible institutions that focus on spiritual connections to ancestors rather than manipulating resources (Cinner 2007). Attempts to integrate customary institutions into multiscale co-management initiatives have been successful under some conditions (Aswani and Hamilton 2004, Cinner and Aswani 2007) but may erode the customary institutions in other situations (e.g., Gelcich et al. 2006).

Madagascar's MPAs experiment with a range of management techniques in attempts to compliment these informal institutions and create functional redundancy at different scales (Elmqvist et al. 2003). For example, managers of the Nosy Atafana MPA demonstrated flexibility in developing locally appropriate temporal restrictions that compliment taboos about farming during certain days. However, in Cap Masoala, attempts to integrate the customary closure with the MPA resulted in sentiments that the sacred area was being desecrated (Cinner 2007). Decentralization of management authority to the stakeholders through the transfert de gestion enables communities to develop locally appropriate rules and regulations (Alcorn and Toledo 1998). The capacity to enforce these rules is often lacking, and, under certain conditions, decentralized control over resources can result in incentives to overexploit local resources, thus weakening ecological resilience (Raik and Decker 2007).

\section{Capacity to organize}

The capacity to organize is an important component of resilience because it enables people to respond to disturbances by drawing upon resources outside of their households. On the positive side, the communities we studied were relatively small, which entailed low transaction costs for cooperation and collective action (Ostrom 1990, Anderies et al. 2004). Our study sites also had a high degree of participation in community decision making, which 
is a key factor in local-level resilience (Tomkins and Adger 2004). Almost all the respondents attended community meetings, and more than $50 \%$ actively participated. In comparison, a similar study in Kenya found that $54 \%$ of respondents were passively involved in decision making and only $36 \%$ were actively involved (Cinner et al. 2009a).

Our sites had a higher degree of group interaction (Ostrom 1990), measured as membership in community groups, than was found in similar studies in Kenya and Tanzania (Cinner et al. 2009a; J. Cinner, unpublished data). However, there was considerable heterogeneity among the Madagascar study sites. Households in Cap Masoala were involved in few community groups. Many community organizations were local in scope and scale, although several groups were regional in focus. All sites had linkages with ANGAP and international conservation NGOs. Despite attempts by ANGAP and the international groups to be participatory, reports from resource users suggested that trust between the community and these organizations was lacking. This was partly because of the law enforcement activities inherent in ANGAP responsibilities.

There were high levels of migration, particularly in Tanjona and Tampolo. Migration levels can be used as a measure of group heterogeneity (Curran and Agardy 2002). Because the vast majority of this migration was from the local area, it was unclear how this affected group homogeneity and the associated transaction costs of collective decision making (Ostrom 1990). Results suggested that, at all study sites, self-organizing following a disturbance may be hindered by a lack of institutional linkages and a lack of trust between communities and park officials (Adger et al. 2005). In the Masoala peninsula parks, migration and minimal involvement in community organizations were also areas of concern. The high degree of livelihood and institutional flexibility as well as aspects of organizational capacity appeared to provide some latent ability for communities in Madagascar's MPAs to respond to both environmental and social change (Berkes and Sexias 2006). However, effectively adapting or responding to change also requires that communities understand the mechanisms that affect resources, can identify potential avenues for managing or mitigating the effects of disturbances, and have the assets and social capital to enact responses. We found these aspects of adaptive capacity generally lacking at our study sites.

\section{Capacity to learn}

Understanding the perceived role of human agency as both a cause of ecosystem degradation and a source for positive change is critical in defining space for experimentation. If people are not able to perceive connections between human activities and the condition of the resources they depend on, they are not likely to support management initiatives that restrict resource use. Likewise, if people do not believe that human activities can improve the condition of resources, they will not be willing to experiment with management alternatives. Although approximately $60 \%$ of our respondents identified direct uses such as overfishing as factors that could impact the number of fish in the sea, there was only a low awareness of the mechanisms through which these factors operate. Despite the high susceptibility of coastal residents to external events such as cyclones, coral bleaching, and the interdependence between marine resource use and cash-crop price fluctuations, few respondents noted connections between these events and the condition of marine resources. Although ecological monitoring does occur at these sites, feedback about the conditions was not effectively reaching the communities, with the result that the potential to adaptively modify regulations based on new information was not being realized.

\section{Assets}

The aspect of resilience we found most lacking was access to assets. Both household assets and community infrastructure were significantly inferior to those in communities in Kenya, Tanzania, Mauritius, and the Seychelles when compared using the same methodology (McClanahan et al. 2008, Cinner et al. 2009b). Addressing basic needs such as food security and shelter may be a crucial first step before communities can begin to meaningfully engage in conservation (Marcus 2001, Cinner and Pollnac 2004).

\section{CONCLUSION, RECOMMENDATIONS, AND LIMITATIONS}

In summary, there were several aspects of locallevel social resilience in Madagascar's MPAs that appeared quite desirable. Flexibility in both livelihood strategies and the formal institutions governing marine resources appeared to provide some latent ability to adaptively manage marine 
resources. Likewise, involvement in community organizations and decision making was high relative to other countries in the region. Conversely, there were several apparent weaknesses in social organization that, if addressed, could help move the social-ecological system of our study sites toward a more desirable configuration. Both households and communities lacked assets. Poor feedback of scientific information to communities was a key factor contributing to low levels of trust between park staff and communities. Low levels of formal education inhibited both the recognition of the mechanisms that affect marine resources and the perception of ways to improve the condition of those resources. There were also poor links between local and larger-scale institutions.

However, there were exceptions to these generalized strengths and weaknesses. For example, households in Sahamalaza had considerably less diverse livelihood portfolios. Levels of formal education at Nosy Atafana were almost double the mean at the other parks. Households in Cap Masoala belonged to only half of the average number of community groups. These exceptions suggest that specific strategies for building resilience will have to occur on a case by case basis. What specific steps might we then take to manage the resilience of Madagascar's MPA social-ecological systems? Based on our own research and the lessons from the Malagasy experience with integrated conservation and development projects, we provide the following recommendations for managing resilience in Madagascar's MPAs:

- Investments in areas such as communitylevel infrastructure, household-level incomegenerating projects, and improved agricultural production are needed to improve the wellbeing of communities (Marcus 2001).

- Investments in formal and informal education for children and adults are necessary to improve the capacity to learn (Peters 1998). This will require building the capacity of teachers and administrators and providing infrastructure for education. Learning institutions need to provide the community with feedback from scientific monitoring information and look for ways to combine scientific and local knowledge (Aswani and Hamilton 2004, Berkes and Sexias 2006).
- There is a clear need to build trust between park staff and local communities. Local communities need to be empowered to govern natural resources and enforce relevant regulations. The decentralization of the transfert de gestion program is a positive step toward enabling communities to make decisions about natural resources, but this must also be coupled with providing rights to resources, capacity building, and institutional strengthening (Kull 2002).

- Challenges to the perceived legitimacy of institutions and law can be improved through increasing the accountability of leaders and the transparency of governance processes (Peters 1998, Kull 2002). Institutions need to ensure adequate cross-scale interaction with local, provincial, and national institutions (Elmvqist et al. 2003).

All of these activities should be pursued in ways that capitalize on community-specific strengths, aspects of strong social capital in decision making, and/or the presence of sociocultural institutions such as taboos that regulate resource use (Cinner 2007, Cinner and Aswani 2007). Our study developed and compared specific resilience indicators across sites. It built upon previous research that identified broad clusters of factors necessary for building social resilience at a range of scales, including the individual (Marshall and Marshall 2007), household (Adger and Vincent 2005), community (Adger 2000, Berkes and Seixas 2006), and nation (Adger and Vincent 2005). We examined a limited suite of indicators and organized our clusters differently from previous studies because of our focus on quantitatively comparing indicators relevant at the scale of the MPA. There were many facets of resilience discussed in previous studies that were difficult to investigate given our methodology. In particular, we did not investigate important process-oriented factors such as learning from crises and the use of social memory as a source of innovation (Berkes and Sexias 2006). These factors may also be important components of social resilience at these sites. Additionally, our study examined resilience at the MPA level, which often aggregated multiple communities. Thus, we did not investigate aspects of resilience operating at other scales such as the individual level (Marshall and Marshall 2007). Consequently, the results we presented here were intended to explore only part of the complex resilience picture. 
Responses to this article can be read online at: http://www.ecologyandsociety.org/voll4/iss1/art41/ responses/

\section{Acknowledgments:}

This project was funded by the Wildlife Conservation Society (WCS) and Coral Reef Degradation in the Indian Ocean (CORDIO). We wish to thank the people of all the study sites for allowing us to work in their communities and for providing assistance. Thanks also to WCS Madagascar and ANGAP for assistance with logistical coordination and cooperation. Special thanks to our field investigators Makoa Jean, Tombo Marcel, Dera Gaston, and Naly. Thanks to T. McClanahan, D. Biggs, and D. Cinner for helpful comments on earlier drafts of this manuscript.

\section{LITERATURE CITED}

Adger, N. 2000. Social and ecological resilience: Are they related? Progress in Human Geography 24:347-364.

Adger, N. 2006. Vulnerability. Global Environmental Change 16:268-281.

Adger, W. N., K. Brown, and E. L. Tompkins. 2005. The political economy of cross-scale networks in resource co-management. Ecology and Society 10(2): 9. [online] URL: http://www.ecology andsociety.org/vol10/iss2/art9/.

Adger, N., and K. Vincent. 2005. Uncertainty in adaptive capacity. Geoscience 337:399-410.

Alcorn, J., and V. M. Toledo. 1998. Resilient resource management in Mexico's forest ecosystems: the contribution of property rights. Pages 216-249 in F. Berkes and C. Folke, editors. Linking social and ecological systems. Cambridge University Press, Cambridge, UK.

Anderies, J. M., A. Janssen, and E. Ostrom. 2004. A framework to analyze the robustness of socialecological systems from an institutional perspective. Ecology and Society 9(1): 18. [online] URL: http:// www.ecologyandsociety.org/vo19/iss1/art18/.
Association nationale pour la gestion des aires protégées (ANGAP). 2002. Parc National Mananara-Nord-Plan d'aménagement et de gestion 2002-2006. ANGAP, Antananarivo, Madagascar.

Aswani, S., and R. J. Hamilton. 2004. Integrating indigenous ecological knowledge and customary sea tenure with marine science and social science for conservation of bumphead parrotfish (Bolbometopon muricatum) in the Roviana Lagoon, Solomon Islands. Environmental Conservation 31:69- 83.

Barrett, C. B., P. P. Marenya, J. Mcpeak, B. Minten, F. Murithi, W. Oluoch-Kosura, F. Place, J. C. Randrianarisoa, J. Rasambainarivo, and J. Wangila. 2006. Welfare dynamics in rural Kenya and Madagascar. Journal of Development Studies 42(2):248-277.

Berkes, F., and C.Seixas. 2006. Building resilience in lagoon social-ecological systems: a local-level perspective. Ecosystems 8:967-974.

Bodin, Ö., O. M. Teng, A. Norman, J. Lundberg, and T. Elmqvist. 2006. The value of small size: loss of forest patches and ecological thresholds in southern Madagascar. Ecological Applications 16 (2):440-451.

Bunce, L., P. Townsley, R. S. Pomeroy, and R. B. Pollnac. 2000. Socioeconomic manual for coral reef management. Australian Institute of Marine Science, Townsville, Australia.

Carpenter, S., B. Walker, M. Anderies, and N. Abel. 2001. From metaphor to measurement: resilience of what to what? Ecosystems 4:765-781.

Cinner, J. 2007. The role of taboos in conserving coastal resources in Madagascar. Traditional Marine Resource Management and Knowledge Information Bulletin 22:15-23.

Cinner, J., and S. Aswani. 2007. Integrating customary management into marine conservation. Biological Conservation 140:201-216.

Cinner, J., M. Marnane, T. McClanahan, and G. Almany. 2006. Periodic closures as adaptive coral reef management in the Indo-Pacific. Ecology and Society 11(1): 31. [online] URL: http://www.ecolog yandsociety.org/vol11/iss1/art31/. 
Cinner, J., T. R. McClanahan, C. Abunge, and A. Wamukota. 2009a. A comparison of livelihoods strategies in fishing communities along the north coast of Kenya. In J. Hoorweg and N. A. Muthiga, editors. Coastal ecology. African Studies Centre, Leiden, The Netherlands, in press.

Cinner, J., T. R. McClanahan, T. Daw, N. A. J. Graham, J. Maina, S. K. Wilson, and T. P. Hughes. 2009b. Linking social and economic systems to sustain coral reef fisheries. Current Biology 19:206-212.

Cinner, J., and R. B. Pollnac. 2004. Poverty, perceptions and planning: why socioeconomics matter in the management of Mexican reefs. Ocean and Coastal Management 47:479-493.

Cinner, J., A. Wamukota, H. Randriamahazo, and A. Rabearisoa. 2009c. Toward communitybased management of inshore marine resources in the Western Indian Ocean. Marine Policy 33: in press.

Colding, J., and C. Folke. 2000. Social taboos: "invisible" systems of local resource management and biological conservation. Ecological Applications 11:584-600.

Cumming, G. S., G. Barnes, S. Perz, M. Schmink, K. E. Sieving, J. Southworth, M. Binford, R. D. Holt, C. Stickler and T. Van Holt. 2005. An exploratory framework for the empirical measurement of resilience. Ecosystems 8:975-987.

Curran, S., and T. S. Agardy. 2002. Common property systems, migration and coastal ecosystems. Ambio 31:303-305.

Duffy, R. 2006. Global environmental governance and the politics of ecotourism in Madagascar. Journal of Ecotourism 5:128-144.

Elmqvist, T. 2004. The forgotten dry forest of southern Madagascar. Plant Talk 35:29-31.

Elmqvist, T., C. Folke, M. Nyström, G. Peterson, J. Bengtsson, B. Walker, and J. Norberg. 2003. Response diversity, ecosystem change, and resilience. Frontiers in Ecology and the Environment 1:488-494.

Folke, C., S. Carpenter, T. Elmqvist, L. Gunderson, C. S. Holling, and B. Walker. 2002.
Resilience and sustainable development: building adaptive capacity in a world of transformations. Ambio 31(5):437-440.

Gallopín, G. 2006. Linkages between vulnerability, resilience, and adaptive capacity. Global Environmental Change 16:293-303.

Gelcich, S., G. Edwards-Jones, M. J. Kaiser, and J. C. Castilla. 2006. Co-management policy can reduce resilience in traditionally managed marine ecosystems. Ecosystems 9:951-966.

Gell, F. R., and C. M. Roberts. 2003. The fishery effects of marine reserves and fishery closures. World Wildlife Fund, Washington, D.C., USA.

Grandcourt, E., R. Rajaonarison, L. Rene de Roland, and C. Andrianarivo. 1999. Status and management of the marine protected areas in Madagascar. International Coral Reef Action Network, UNEP-WCMC, Cambridge, UK.

Gunderson, L. 1999. Resilience, flexibility, and adaptive management-antidotes for spurious certitude? Conservation Ecology 3(1): 7. [online] URL: http://www.consecol.org/vol3/iss1/art7/.

Harper, J. 2002. Endangered species. Carolina Academic Press, Durham, North Carolina, USA.

Henry, G. T. 1990. Practical sampling. Sage Publications, Newbury Park, California, USA.

Hughes, T., D. R. Bellwood, C. Folke, R. S. Steneck, and J. Wilson. 2005. New paradigms for supporting the resilience of marine ecosystems. Trends in Ecology and Evolution 20(7):380-386.

International Panel on Climate Change (IPCC). 2007. Climate change 2007: impacts, adaptation and vulnerability; summary for policymakers. IPCC, Geneva, Switzerland.

International Trade Centre Market News Service. 2007. Spices. Issue no. 5, October 2007. UNCTAD/WTO, Geneva, Switzerland.

Janssen, M. A., Ö. Bodin, J. M. Anderies, T. Elmqvist, H. Ernstson, R. R. J. McAllister, P. Olsson, and P. Ryan. 2006. A network perspective on the resilience of social-ecological systems. Ecology and Society 11(1): 15. [online] URL: http: //www.ecologyandsociety.org/vol11/iss1/art15/. 
Kull, C. 2000. Deforestation, erosion, and fire: degradation myths in the environmental history of Madagascar. Environment and History 6:423-450.

Kull, C. 2002. Empowering pyromaniacs in Madagascar: ideology and legitimacy in communitybased natural resource management. Development and Change 33:57-78.

Lambek, M. 1992. Taboo as cultural practice among Malagasy speakers. Man 27:245-266.

Lambek, M. 1998. The Sakalava poiesis of history: realizing the past through spirit possession in Madagascar. American Ethnologist 25:106-127.

Lebel, L., J. M. Anderies, B. Campbell, C. Folke, S. Hatfield-Dodds, T. P. Hughes, and J. Wilson. 2006. Governance and the capacity to manage resilience in regional social-ecological systems. Ecology and Society 11(1):19. [online] URL: http:/ /www.ecologyandsociety.org/vol11/iss1/art19/.

Lingard, M., N. Raharison, E. Rabakonandrianina, J. Rakotoarisoa, and T. Elmqvist. 2003. The role of local taboos in conservation and management of species: the radiated tortoise in southern Madagascar. Conservation and Society 1. Available online at: http://www.conservationandsociety.org/ c s 1 2-3-marlene.pdf.

Loudon, J., M. Sauther, K. Fish, M. HunterIshikawa, and J. Ibrahim. 2006. One reserve, three primates: applying a holistic approach to understand the interconnections among ring-tailed lemurs (Lemur catta), Verreaux's sifaka (Propithecus verreauxi), and humans (Homo sapiens) at Beza Mahafaly Special Reserve, Madagascar. Ecological and Environmental Anthropology 2:54-74.

Marcus, R. 2001. Seeing the forest for the trees: integrated conservation and development projects and local perceptions of conservation in Madagascar. Human Ecology 29:381-397.

Marcus, R., and C. Kull.1999. Setting the stage: politics of Madagascar's environmental efforts. African Studies Quarterly 3:1-7.

Marshall, N. A., and P. A. Marshall. 2007. Conceptualizing and operationalizing social resilience within commercial fisheries in northern Australia. Ecology and Society 12(1):1. [online]
URL: http://www.ecologyandsociety.org/vol12/iss1/ art1.

McClanahan, T. 2007. Testing for correspondence between coral reef invertebrate diversity and marine park designation on the Masoala Peninsula of eastern Madagascar. Aquatic Conservation: Marine and Freshwater Ecosystems 17:409-419

McClanahan T. R., J. Cinner, J. Maina, N. A. J. Graham, T. M. Daw, S. M. Stead, A. Wamukota, K. Brown, M. Ateweberhan, V. Venus, and N. V. C. Polunin. 2008. Conservation action in a changing climate. Conservation Letters 1:53-59.

McClanahan, T., H. Glaesel, J. Rubens, and R. Kiambo. 1997. The effects of traditional fisheries management on fisheries yields and the coral-reef ecosystems of southern Kenya. Environmental Conservation 24:105-120.

Myers, N., R. A. Mittermeier, C. G. Mittermeier, G. A. B. da Fonseca, and J. Kent. 2000. Biodiversity hotspots for conservation priorities. Nature 403:853-858.

Ostrom, E. 1990. Governing the Commons: the evolution of institutions for collective action. Cambridge University Press, Cambridge, UK.

Peters, J. 1998. Transforming the integrated conservation and development project (ICDP) approach: observations from the Ranomafana National Park project, Madagascar. Journal of Agriculture and Environmental Ethics 11:17-47.

Pollnac, R. B. 1998. Rapid assessment of management parameters for coral reefs. University of Rhode Island Coastal Resources Center, Narragansett, Rhode Island, USA.

Pollnac, R. B., and B. Crawford. 2000. Assessing behavioral aspects of coastal resource use. University of Rhode Island Coastal Resources Center, Narragansett, Rhode Island, USA.

Pretty, J., and H. Ward. 2001. Social capital and the environment. World Development 29:209-277.

Putnam, R. D. 1993. Making democracy work. Princeton University Press, Princeton, New Jersey, USA.

Raik, D. B., and D. J. Decker. 2007. A multisector 
framework for assessing community-based forest management: lessons from Madagascar. Ecology and Society 12(1):14. [online] URL: http://www.ec ologyandsociety.org/vol12/iss1/art14/.

Rakotoson, L., and K. Tanner. 2006. Communitybased governance of coastal zone and marine resources in Madagascar. Ocean and Coastal Management 49:855-872.

Randriamanantsoa, B. J. D., and J. C. Lope. 1999. Suivi bio\&\#233cologique des récifs des trois parcs marins et d'un site touristique dans le Presqu'ile Masoala; rapport definitif. L'équipe cellule des océanographes de l'Université de Toliara (COUT) à l'Institut halieutique et sciences marines de Toliara, Toliara, Madagascar.

Reuters. 2007. Madagascar: successive cyclones bring Madagascar to its knees. Available online at: http://www.alertnet.org/thenews/newsdesk/IRIN/ d66a9da9de13df21bf834bb6c20dfe10.htm.

Ruud, J. 1960. Taboo: a study of Malagasy customs and beliefs. Oslo University Press, Oslo, Norway.

Sussman, R. W., G. M. Green, and I. K. Sussman.1994. Satellite imagery, human ecology, anthropology and deforestation in Madagascar. Human Ecology 22:333-354.

Tompkins, E. L. 2005. Planning for climate change in small islands: insights from national hurricane preparedness in the Cayman Islands. Global Environmental Change 15:139-149.

UN. 2007. Millennium development goals, Madagascar. Available online at: http://mdgs.un.org/ unsd/mdg/Data.aspx downloaded 21/9/07.

Walker, B., S. Carpenter, J. Anderies, N. Abel, G. Cumming, M. Janssen, L. Lebel, J. Norberg, G. D. Peterson, and R. Pritchard. 2002. Resilience management in social-ecological systems: a working hypothesis for a participatory approach. Conservation Ecology 6(1): 14. [online] URL: http ://www.consecol.org/vol6/iss1/art14.

Walsh, A. 2002. Responsibility, taboos and "the freedom to do otherwise" in Ankarana, northern Madagascar. Journal of the Royal Anthropological Institute 8:451-468.
West, P., and D. Brockington. 2006. An anthropological perspective on some unexpected consequences of protected areas. Conservation Biology 20:609-616.

Wilkinson, C. 2000. Status of coral reefs of the world: 2000. Australian Institute of Marine Science, Townsville, Australia. 